July-December 2020

Volume: 10, No: 2, pp. $227-243$

ISSN: 2046-4436

e-ISSN: $2046-4444$

https://journals.tplondon.com/bc

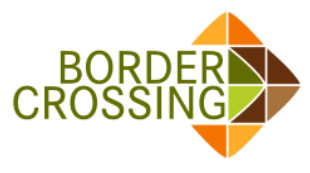

Received: 10 June 2020 Accepted: 17 July 2020

DOI: https://doi.org/10.33182/bc.v10i2.1046

\title{
Stateless Syrians in Turkey and Lebanon
}

Deniz Aşkın ${ }^{1}$

\begin{abstract}
Emigration began in Syria following the civil war has caused a break in the legal citizenship bonds of millions of Syrians with their country, especially for those settled in neighbouring countries. The open door policy implemented by Turkey and Lebanon and the two countries hosting of the majority of this migrated population have made registration and some services in these countries even more intricate. Generally, the Syrians but especially children born outside of Syria can only be recognised as Syrian practically but not officially. People in this group who can be identified as de facto stateless face the risk of not enjoying fundamental human rights if they are not enrolled in the countries where they moved. In this respect, both being stateless and unregistered in the receiving country cause these individuals to face double victimisation. In this context, the situation experienced in Turkey and Lebanon was examined within the framework of de facto statelessness concept with reference to culture, identity, and integration.
\end{abstract}

Keywords: de facto statelessness; Syrians; Turkey; Lebanon; nonregistration; stateless children.

\section{Introduction}

A suicide attempt by Muhammad Bouazizi in Tunisia in 2010 was the beginning of important social and political developments in the Middle East. The events in the Arab geography aiming at the change of governance and affecting the fundamental dynamics, especially in Egypt, Libya, and Syria, have led to the massive migrations that have impacted almost all countries of the World by going beyond the borders of the countries. This situation has set the groundwork for social and political debates regarding the residence or return of Syrians in Turkey and Lebanon, where they are allowed to passage through the border. However, it is also possible to express that Syrians have built the backdrop of new problems due to their citizenship being idle. The "old" phrase used by Syrians who remained away from their own country indicates the ambiguous situation of Syria and their old lives. Syrians, who cannot reach the documents they left behind because of the war and now cannot prove that they are Syrian, can face various difficulties in the countries they have migrated. The obligation to renew the passports and identity cards that they have brought along with them and have been deformed over time is a reality that most of the Syrians cannot afford because of cost and security reasons. As a result of these components and loaded negative arguments, the definition of Syrian used for Syrians staying in foreign states today does not go beyond responsibilities and sanctions for certain individuals. With a reverse reading, citizenship emerges

\footnotetext{
${ }^{1}$ Assist. Prof. Deniz Aşkın, Department of Sociology,Bitlis Eren University, Bitlis, Turkey. E-mail: denizaskin13@gmail.com

${ }^{2}$ https://www.economist.com/middle-east-and-africa/2014/10/23/the-loss-of-a-nation
} 
as the starting point of the bond and mutual responsibility established between individuals and the State. In a study conducted by UNHCR $(2015$, p. 15), stateless children were asked to identify themselves, then they often identified themselves with an adjective that contains negativity such as 'invisible', 'strangers', 'keeping a low profile', 'worthless' and 'a stray dog', reflecting their point of view towards themselves.

Because individuals who have settled in the territory of other countries by migrating from Syria and citizenship is reserved via the father as required by Syria's own constitution, the emergence of sociological problems as well as various legal problems are seen today. The UN $(1954$, p. 6), defines a stateless person as one "who is not considered as a national by any State under the operation of its law". This definition deprives the individual of fundamental rights and prevents the individual from imposing the responsibility of any State. In this respect, "Statelessness is not merely a legal problem, but it is a human problem" (Batchelor, 1998, p. 159). That is why statelessness becomes the source of the problems that individuals will experience in the future. The absence of an individual's commitment to a State or not being registered to a State means that he/she is deprived of important fundamental rights such as education, health, and travel. This situation, which resembles a flag-free ship in the middle of the sea (Altuğ, 1963, p. 202), always carries individuals to a vulnerable position. This study mainly focuses on discussing the legal position of the people who have been immigrated from their country of origin for various reasons and their reflections on social life. In other words, it aims to discuss the statelessness of individuals defined as foreigners, asylum seekers, refugees, and migrants because of staying outside of their own country and to discuss the transfer of this situation to the next generation on a sociological basis.

Turkey and Lebanon have many common points in the Syrian migration share, however, some of the main reasons why these two countries are dealt with in the context of this study come to the forefront. First of all, these countries host most of Syrian immigrants. These countries are going through a similar process as there is a lot of Syrian immigrants, which will affect the registration process and use of their basic human rights in a coordinated manner. However, the fact that Syrians are "strangers" allows each country to use different techniques and programs. Turkey has experience in immigration and the coordinated working with the United Nations (UN), which affects its programs, while the sharing of political power in Lebanon according to the religious population and political groups in the country have severely influenced the migration process of Syrians to the country and subsequent programs. At this point, according to the data of 28 February 2019 compiled by UNHCR (2019), Turkey currently hosts the most Syrians as 3,644,342 immigrants. Turkey is followed by Lebanon with 946,291 people in second place. The second reason for the selection of these two countries is that both countries have a border with Syria and allow immigrants to use the borders in case of crisis. The third reason is that both countries initially adopt the open door policy for immigrants fleeing the crisis of Syria. The fact that this policy then allowed the expansion of an unscheduled immigrant in both countries, and the formation of suitable ground for the disruption of the registration process, and the difficulty of the supervision caused these two countries to come together in the context of this study. However, the point that makes this study important and distinctive is that it shows a comparative way of how Turkey and Lebanon are able to manage the migration today, depending on the similar points for the migration from Syria. As explained in detail below, this phenomenon is discussed in the context of the de facto statelessness of Syrians in both countries. 
The number of people worldwide, who can be defined as stateless, is not known clearly because of their inability to be registered. However, the social, economic and political crises that occur in the World lead to the emergence of different cases of statelessness. The statelessness generally can be examined in two separate categories. The first is "de jure "and the other is "de facto" statelessness. Under normal circumstances, every individual is given the nationality of the region, according to the citizenship of their parents. These rights of individuals ensured by laws are an absolute precaution of the problem of statelessness while minimising arbitrary situations. Depending on where individuals have developed their own citizenship bonds, place transfers the citizenship rights to individuals to be transferred to their descendence. Despite this situation which is fixed by both national and international agreements in theory, it can lead to significant discussions and deadlock in practice. First of all, it is possible to evaluate the persons, who are not defined as citizens by the State which they are born in or by another State, in the category of de jure statelessness. Although such people have known citizenship that is valid in his country but is not active and valid in the international arena, these individuals are also included in the de facto stateless group. Therefore, the de jure and de facto statelessness are essentially assessed considering whether a person has a State or not and whether individuals can obtain this right legally. On the other hand, de jure statelessness can be confirmed as a usual situation with the law and refers that the citizenship, known as the basic human right, is not given to the person by the hosting country. In this respect, de jure statelessness is a situation that lacks a legal basis and develops without a legal obligation on the hosting land. For example, when Rohingya Muslims became refuge in Bangladesh, a neighboring country of their own country, they were unable to find a State or national foundation that possessed them in the process of being returned, and this is a concrete result of de jure statelessness (Adhikar, 2013, p. 77; Ateş, 2017, p. 174; Sengupta, 2018; Basavapatna, 2018; Velath and Chopra). The de facto statelessness, on which this study will be theoretically based, refers to a phenomenon that can be shown as the situation of refugees. That is why refugees were legally able to obtain citizenship in the State they were in and to comply with the rules of their own State. Now, they are deprived of this right because they are not in their own country.

In a sense, de facto statelessness that develops depending on the individual himself arises when the person cannot use his/her existing right. In this respect, "De facto stateless persons are persons outside the country of their nationality who are unable or, for valid reasons, are unwilling to avail themselves of the protection of that country" The essential condition of the occurrence of the de facto statelessness is to remain outside the boundaries of their own State. This situation refers that individuals are able to obtain the right to be citizen and to be able to benefit from the necessary services in their homeland, but they are deprived of the protection of the State by being outside of the country borders and by not being able to go to their own country and confirming their citizenship. For the current reasons, this is a process in which people cannot contact their country and not benefit from the rights that the State has provided and even their own State cannot interfere with the negative situation of their citizens (Massey, 2010, p. 61). The de facto statelessness makes individuals vulnerable to dangers, so the relationship between individual and State is minimised by the inability of a person to benefit from the opportunities provided by their own State. The de facto statelessness, which refers to a process in which an individual loses responsibility for their State, even the State loses responsibility for its own citizens with a wider meaning, reduces the relationship between State and citizen to the 'verbal' level. In this study, the situation of the Syrians living in Turkey and Lebanon deprived of citizenship rights and the ground that created this phenomenon were opened for discussion within the scope of the de facto concept. The fact that both countries 


\section{Stateless Syrians in Turkey and Lebanon}

have different characteristics and traditions from social, political and cultural perspectives brings these countries to the common ground in the context of immigration they receive from Syria. However, although Turkey and Lebanon initially adopted the open-door policy for Syrians, their policies for migrators in their own countries are changing as the second phase of the process. In other words, registration, coordination, integration, political participation, and managing the benefits of basic humanitarian rights differentiate the two countries at the point of applied policies. In light of this information, the institutional reproduction of "de facto statelessness" in Turkey and Lebanon is focused in this study, and the results are discussed on a sociological base.

The 20th century, which Castles and Miller (1998) described as an immigration age, witnessed an important process with the effect of immigration waves in the $1990 \mathrm{~s}$, as well as, many great migration movements. Migratory movements that have long effects for many years are attracting attention so that the new generations identify themselves once again. This situation has been tried to be prevented with various international agreements focusing on the stateless generations as a result of such major events and visible migration phenomenon. On April 12, 1930, Some Issues Concerning the Conflicts of Nationalism and the Special Protocol on Statelessness were signed on the same date by League of Nations. These agreements, whose main objective is to prevent the phenomenon of statelessness occurring by birth, increased their visibility later due to events occurring at the global level. with the Universal Declaration of Human Rights (1948), this situation has been come forefront and described in the later period. In this context, Item-15 is as follows: 1"Everyone has the right to a nationality. 2-No one shall be arbitrarily deprived of his nationality, nor denied die right to change his nationality". However, this item is insufficient to solve the problems that arise in practice. Considering the subsequent studies within the UN, it is understood that previous agreements were inadequate in the process (Altuğ, 1963, p. 202). Considering the precautions taken at this point, International organisations signed agreements aimed at eliminating the phenomenon of statelessness until 2030 with the UN Conventions on Statelessness, 1961 the United Nations Convention on the Reduction of Statelessness, and the Convention on the Rights of the Child (OCHA, 2017, p. 4). As can be understood from the names of the contracts, while the convention in 1954 focuses on the status of stateless persons (Hadimoglu and Teksoy, 2013, p. 223), the 1961 convention refers to pursue a working policy aiming at the elimination of this phenomenon. Further backward, the 1954 agreement is a continuation of the refugee agreement signed in 1951 and focuses on defining and improving the conditions of this phenomenon, rather than solving the phenomenon of statelessness. This agreement, which is also an attempt to identify the phenomenon of de jure statelessness, does not include the definition of de facto statelessness, which is more dynamic and has a wider production mechanism. The de facto statelessness, which points to a process in which the citizenship relations with the State is neutralised, was also deprived of a legal base, except for the definition of statelessness in the 1954 convention (Malischewski, 2018). The 1961 agreement, even if, shows the attempt to resolve the statelessness occurring from birth based on the law, it could not bring an adequate solution to the existing statelessness, or no sanctions were imposed for arbitrary deprivation of citizenship (Blitz, 2009, p. 6). The Convention to Reduce the Number of Cases of Statelessness ${ }^{3}$, signed in Bern in 1973, is also an example of an attempt to consider the problem of statelessness as a global issue and to reduce potential victimisation.

05801883.pdf

https://www.tbmm.gov.tr/tutanaklar/KANUNLAR_KARARLAR/kanuntbmmc058/kanuntbmmc058/kanunt 


\section{The Phenomenon of Statelessness and Syrian Citizenship in International Treaties}

Citizenship refers to the starting point of the rights and responsibilities of individuals when expressing their belonging to certain land and State. Individuals/groups on the World cannot sometimes obtain this right by birth for different reasons. As discussed above, this case, which is available for discussion in different categories, prepares the ground for the experiencing of important social and political problems. Individuals, who are born on other countries but who do not take citizenship, in the same way, who cannot establish the nationality bond with their own country, or who cannot document this situation, have constant rights with international law, but they can face the problem of statelessness. The absence of a State that individuals can feel a sense of responsibility to, the deprivation of the State which can be benefited from its sheltered structure, pushes the individuals to an 'unowned' position in the international arena and makes them vulnerable compared to the people with citizenship. This is why the Council of Europe and the UN are trying to minimise the phenomenon of statelessness as it prevents the use of fundamental human rights (Batchelor, 1998, p. 157; Hadimoğlu and Teksoy, 2013, p. 224). Moreover, in the first and fourth articles ${ }^{4}$ of the report prepared by the United Nations International Law Commission, the ways in which individuals acquire citizenship are enlarged and necessary efforts are made to ensure their registration to a State citizenship at least for a temporary short time to prevent from being stateless.

An attempt to identify and resolve the phenomenon of statelessness, perceived as a global problem, with international agreements was assessed mostly over existing individuals, and the rights were explained. The first comprehensive convention, which states that children have the right to a nationality as soon as they are born, is based on the Declaration of the Rights of the Child published by the United Nations. That is why this contract focuses on the rights that an individual will have by birth. In this respect, the individuals have the right to become a citizen and to be named and to be cared for by their parents when they are born. The article 7.1 of the Convention (UN, 1989, p. 3) guarantees this right of the child with the following statement; "The child shall be registered immediately after birth and shall have the right to a name from birth, the right to acquire a nationality and, as far as possible, the right to know and be cared for by his or her parents." The next article 7.2 says that "States Parties shall ensure the implementation of these rights in accordance with their national law and their obligations under the relevant international instruments in this field, in particular where the child would otherwise be stateless." Using this right proves the existence of an individual while ensuring responsibility for the official authority. In addition, the birth certificate and citizenship establish a bond between persons and their families and determine the individual's belonging in the international arena as an upper stage (Reynolds and Grisgraber, 2015, p. 2-3). When viewed to the above items, many open items are put in the convections to prevent people from statelessness, although the reflection of this situation in practice is not fully realised as it requires both a long process and cost.

The study conducted by NRC $(2017$, p. 3$)$ on Syrians in Lebanon, Jordan, and Iraq concluded that $52 \%$ did not have the marriage agreement, marriage certificate, or family registration guide that could prove their marriage. However, it is not possible to evaluate those who live outside of Syria in a single category. The first category refers that they were married in Syria, but not registered, the

\footnotetext{
4 For detailed information of the Commission's articles; General Assembly (30 January https://www.unhcr.org/42bc068d2.pdf

Copyright @ 2020 BORDER CROSSING
}

2001) 


\section{Stateless Syrians in Turkey and Lebanon}

second category refers that their marriage is registered in Syria but their documents may be lost or deformed during the migration, the third category refers that they were married in the country they migrated but it is not registered. These three categories cause children to remain stateless. According to Syrian law, marriages made abroad must be reported to the Syrian consulate within the next 90 days. However, Syrians are hesitant about being recorded for various reasons. At this point, one of the main reasons why Syrian migrants do not want to be included in the registration system is their uneasiness that the Syrian regime will know where they reside. In this respect, the fact that they do not want to be deciphered, and the shortage of information on this subject cause people to stay away from the registration system. However, another reason regarding security is the migration to Europe, which Syrians mostly hope, and which still stands as a major obstacle to being involved in the registration system. As a result of these, a non-registration and statelessness situation is formed. In addition, as a tradition in Syria, the informing authorities after 2 months of birth to prevent the registration fee from going for nothing, considering the possibility of dying of baby, is another important obstacle to the registration of newborn babies (Reynolds and Grisgraber, 2015, p. 6- 9).

The states where Syrians emigrated have achieved successful results, especially with the help of international organisations to facilitate registrations on births, deaths, and others. However, the Syrians encounter a different procedure from their country, causing them to face difficulties in the new countries where they migrate. For example, in the case of a Syrian couple having a new baby, the father fulfills his own responsibility by declaring it to the competent authorities. The competent authorities make it possible to use the baby's basic rights by registering the newborn baby in the "family registry booklet", but a special identification certificate for the baby (up to 14 years of age) is not provided. This situation allows the Syrians to give birth notification in particular but prevents them from getting the birth certificate for the infant. The operation of the process in Syria in this way causes people who are away from their own country and newborn babies to be de facto stateless, unregistered, but most importantly, unaware of this issue (ILAC, 2017, p. 2).

The absence of a birth certificate causes families to hesitate in their return. They try various ways to protect the integrity of the family and to eliminate such dangers, which may cause the child to face much more serious problems in the future, through palliative solutions. For example, this causes people to borrow the identities of their close relatives to do their own official works, or take the risk of taking the documents they left behind by going to Syria. Because, if the child does not have its own identity certificate until the age of 14 in Syria and does not complete the required operations through the family registration system, it makes families think that these will prevent their children from benefiting from basic human rights such as education, health, heritage, and citizenship. Therefore, $91 \%$ of people interviewed did not have a family registration system (NRC, 2017 , p. 3), which causes them to think that their children will face such problems in their return to Syria. In addition, according to UNCHR $(2016$, p. 10; 2014) estimates, there were 709.000 children under the age of four from the beginning of the civil war until 2016, however, 300,000 of them were born as refugees away from the land they belong to. An important part of these children born outside of Syria confronts de facto statelessness as a common problem. According to the Syrian Constitution, persons can only obtain Syrian citizenship through his own father. However, the war in Syria left $25 \%$ of the children without father, which carries the question of how the registrations will be and how they will be a citizen. Considering the records (AFAD, 2013, p. 32), 34\% of Syrians remaining in the camps in Turkey, and $29 \%$ of remaining outside the camps lost at least one of their family members during the war. The women who cannot legally transfer their citizenship to their 
own children are excluded from the process, and men cannot pass on this right to the next generation in cases of war, loss or death, both realities cause the problems to reproduce.

According to the Syrian state constitution, marriage requires two processes, although it is the first stage of establishing a family. First, the marriage of a man and woman is approved by the courts of their own religion, then the State records are processed, and each party is given a copy. This procedure is clearly based on the rights and identity of the next generation (UNCHR, 2018, P. 16). Syrian citizens must be reported to the official authorities within 30 days after the birth of a child under normal circumstances. It is necessary to show that the individual is a Syrian citizen and, in a sense, is not a stateless person, to be able to obtain an ID card when he/she is 14 years old. The birth certificate contains information indicating that "the birth is from a marriage", as well as, name, place, date of birth and national identity, which shows an individual's identity and responsibility until the age of 14 when the individual receives his/her official identity card. According to Syrian law, an individual without a birth certificate cannot benefit from the basic rights of the country such as education, travel, and health. Moreover, unregistered individuals cannot prove that they are Syrian citizen, nor will be able to obtain an ID card when in 14 years old. According to the Constitution of the Republic of Syria, when every individual is 14 years old, an ID card application is made by the persons responsible for him/her. However, this should be done within a year (ILAC, 2017, p. 1; UNCHR, 2018, p. 4). Otherwise, taking a new identity card by an individual will bring a long procedure and criminal responsibility.

\section{Registered and Unregistered Statelessness Syrians in Turkey}

The problem of the statelessness that the Republic of Turkey faced shortly after its establishment allowed it to have important experience. Between 1933-1945, during National Socialism in Germany, A. Hitler canceled many individual citizenships, mostly for Jews, and a part of them came to Turkey, which started the debate on Haymatlos. The word "Heimatlos" in Germany passed to Turkish as Haymatlos(z) and was used to express the position of stateless people. Even still, this concept, especially used by Turkish security units, has increased the state's experience of developing a systematic way to intervene and solve structural problems. This will mark the origin of the encounter with the stateless phenomenon of the young republic (Arslan, 2014, p. 124). Many years passed up to now has also strengthened the process of gaining institutional culture and system for Turkey in terms of migrants, especially from the Balkans and the Middle East by taking mass immigration. Following the "Arab Spring" that erupted a few years ago, social rebellions have caused political changes, which has appointed Turkey's policies towards the migrant masses from Syria, and the inheritance of the previous corporate heritage determined the direction of the following developments.

Turkey worked in coordination with the UN to create a database after the decision to take the Syrian immigrant population. Firstly, the information was compiled by GOCNET and then coordinated with POLNET, the database was created with the two mentioned software. In particular, the registration procedures of the Syrians were performed, and some information necessary for them to be able to access the basic humanitarian services in a healthy way was recorded, and the identification numbers were given to foreigners. Today, with this system in Turkey, information such as location, transition, marital status, childbirth is recorded (UNCHR, 2016, p. 36). After the displacement of migrants, they update this information via The Directorate General of Migration Management (DGMM) and inform the authorised units so that the circulation within the country is 


\section{Stateless Syrians in Turkey and Lebanon}

also recorded. This way, Syrians within the scope of temporary protection are required to apply and update their information to take advantage of the necessary transactions when they move in the country. With these records, which are provided by authorised units (DGMM), it is possible to reach the number of Syrians in the cities in Turkey. Another important aim of this system recording Syrians is to solve the security problem and minimise informality (Mackreath and Sagnnic, 2017, p. 20). In this way, as a result of coordinated studies with the General Directorate of Security, the registration, renewal or determination of persons in the search lists are arranged. However, the need to register the Syrians who have moved to Turkey carries the purpose of providing the necessary services, also, the desire of the newborn children to be registered also constitutes an important dimension of the subject.

According to the ombudsman institution report (2018, p. 113.153), from the date of the Syrians began to migrate to Turkey until the date of December 2017, a total of 276.158 birth was reported in Turkey. Syrian infants born in Turkey before the war have could be registered as a citizen of Syria, via the Syrian Consulate in Turkey by asking and confirming the documents. However, it is seen that the alternative false identities have been started to be produced, as the Syrians consider their consulate to be a potential danger, with the fear of to be deciphered. The cost of these identities, which have been obtained in exchange for approximately 1000 dollars, and on the other hand, the idea of to be registered as opposition by the Syrian consulate has led to the absence of identity and nonregistration, especially for newborn babies. It is seen that this system is reduced to an easier and risk-free dimension in the advancing process in Turkey. Therefore, it was provided that a father and mother having a newborn baby could submit their documents to the Ministry of Interior within 30 days, and in return, they could receive their birth certificates. However, because it is not known by Syrians, it cannot be said that there is sufficient consciousness in the registration process. Because immigrants are still reluctant to follow the process by thinking that the transactions are being carried out at the Syrian consulate. At this point, a public education campaign was launched to raise awareness of the importance of registration in Turkey. While the recording of Syria in Turkey is carried out through local authorities, the situation of nonregistration and deprivation of fundamental rights begins if the displaced Syrians do not report these displacements to the authorities. Syrians, who do not report the address change to the authorities, are not able to gain access to the services of health, education and other social rights made by institutions (other than an emergency) for both themselves and their children (Reynolds and Grisgrabber, 2015, p. 6). The gradual improvement of the processes of Syrians necessitates new works and opportunities, also, Turkey's work on this issue is coordinated with the UN. With the above-mentioned agreements, the aim of the UN to prevent and completely eliminate the phenomenon of statelessness in the next 10 years can be stated to have been effective in taking these steps. In addition, making the system ready and solving the systemic problems were accelerated in Turkey in order for both security and making Syrians benefit from the fundamental rights. In this respect, registration refers to access to the services offered by the hosting State rather than giving citizenship to the individual. However, it causes unregistered individuals to experience the problem of statelessness more intensively.

In Turkey, based on Article 91 of Law on Foreigners and International Protection, the positions of Syrians are determined as follows. "Temporary protection may be provided for foreigners who have been forced to leave their country, cannot return to the country that they have left, and have arrived at or crossed the borders of Turkey in a mass influx situation seeking immediate and 
temporary protection ${ }^{5 \%}$. Millions of Syrians having to migrate from their countries caused serious social crises in neighboring countries, especially in Turkey. In addition to the millions of migrated victims described as "Syrian", it is strongly likely that infants and children, who could even not be considered as migrants or Syrians, will stand out as a more visible social problem in the near process. Turkey, as one of the prominent countries in this regard with the open-door policy for Syrians, can face various problems at the issue of registration as a result of unreported de facto newborns. But at this point, one of the most important issues that stand out as an international issue is especially children born in a different country, who cannot register their citizenship due to political problems in their country.

Considering the Syrian children, it is seen that the problem is gained in a more important dimension depending on the size of the mass. At this point, it is necessary to express that the realisation of registration systems is currently an important issue for the migration-receiving country, otherwise, the child's identity is inevitable to be reduced to the verbal definition of "Syrian" in case of non-registration.

According to the article 8 of the second section in the Turkish Citizenship Law no 5901, entitled Acquisition of Turkish citizenship, (1) "A child born in Turkey, but acquiring no citizenship of any State by birth through his/her alien mother or father is a Turkish citizen from the moment of birth. (2) A child found in Turkey is deemed born in Turkey unless otherwise proven". This law is, in fact, open to the interpretation in terms of being a Turkish citizen for infants who cannot prove that he is a Syrian citizen due to his father. In other words, with the requirement to be born in Turkey, people who do not acquire citizenship in any country are open to the interpretation of whether they will receive Turkish citizenship directly. However, this law article may cause controversy about the status of "Syrian" children born in Turkey.

While the aforementioned article is open to interpretation, the competent authorities in Turkey think in the direction that their children will be a direct Syrian citizen because the homeland of parents is known (Gale, 2016, p. 24). In a parliamentary debate that confirms this situation, Süleyman Çelebi, a member of Parliament, raised the issue of Syrians' transition to Turkish citizenship, and Muammer Güler, the interior minister of the period, answered the question. Güler, on the basis of Article 8 of the constitution, reminded them of the law; "The child, born in Turkey and unable to gain citizenship from any country due to its foreign parents and fathers, is a Turkish citizen by birth". He also interpreted that "the children of Syrian refugees, born in Turkey, are not in the question of gaining Turkish citizenship because they gain Syrian citizenship due to their parents ${ }^{6 ،}$. With this statement, children born in Turkey from a Syrian mother and father are also considered as Syrian citizens in a de facto sense, although not registered. Even though the registration process is being carried out in Turkey, the fact that the registered Syrian children have not a State where they are citizens puts them directly under a stateless position. In the conceptualisation of de facto statelessness mentioned above, their citizenships, which are reduced to the verbal level, do not have any legal reciprocity. Therefore, the registration system in Turkey is literally the product of an initiative aimed at ensuring the supervision, safety, and coordination of Turkey in its internal affairs. This is particularly affecting individuals born as refugees or who have not been able to obtain the right to citizenship even though they born in their country and cannot

\footnotetext{
${ }^{5} \mathrm{http} / /$ www.goc.gov.tr/files/files/eng_minikanun_5_son.pdf

${ }^{6} \mathrm{http}: / /$ www.milliyet.com.tr/2-bin-543-suriyeli-evlenip-turk/gundem/detay/1818231/default.htm

Copyright @ 2020 BORDER CROSSING
} 


\section{Stateless Syrians in Turkey and Lebanon}

prove it on a legal basis. In this regard, registration is a detection system that is used to prove that the person exists. At this stage of the process, it is observed that the problem of registered statelessness has emerged. "Registered statelessness" refers to the registration of the existence of persons born on the territory of another country and bound to a State as de facto. For this reason, to reach basic needs, the priority is concentrated in registration rather than citizenship. In other words, the problem of citizenship remains in second place with their registration so that the persons can stay at the borders of Turkey and benefit from the services offered to them. However, as mentioned in detail below, the Syrians in Turkey encounter some institutional problems at the registration of their newborn babies, but at some points, they seem reluctant.

In Turkey, Syrian children are mostly born in hospitals. In the hospital, therefore, a birth of notification is given in accordance with the expression of the mother or father, including the name of the baby, date of birth, place of birth and the information of the parents. With this document taken from the hospital, a person goes to the migration directorate of the province. However, in normal circumstances, the mother's declaration is not sufficient, but the father's information documents including (birth registration certificate, ID, passport, etc.) or the father himself must be present during the declaration. Otherwise, registration will not be made. In spite of this, considering war conditions and fundamental human rights in Turkey, and in case of need, a certificate of registration is given to the baby after just verbal engagement, and the opportunity to benefit from the health, social services, and education is provided.

The registration of the Syrians in Turkey has sometimes caused a delay due to the intensity of registry processes previously done by the safety units, while the thought of the Arabic-speaking staff being not enough have raised immigrants' concerns about expressing themselves and reduced their application. Similarly, the Syrian records done by the neighborhood local authorities show that the theory is really different from the truth in practice. It is quite common for Syrians who are outside of the camp in Turkey to stay in the same house as a 4-5 family, while the registries of local authorities may have a family record per household. The fact that the nomadic groups in Syria (Doms) are culturally far from the record systems affect their lives in Turkey. Those Doms who do not want to be registered are continuing to be an important source in the increase of informality in Turkey (Mutlu et al., 2016, p. 33). This causes unregistered de facto statelessness to be concentrated in some groups. There is a need to draw attention to some points. The first of these is that babies are not visible because the process of registering newborn children is not known, or the need for it is not understood. In this respect, both the records kept by the State and the lack of basic rights in the process of statelessness phenomenon are emerging together. In this respect, moreover, becoming both unregistered and statelessness allow people to face a risk of "double victimisation". At this point, the persons are defined with a cold title "Syrian", which reduces them to only verbal level.

\section{The Stateless Syrians in Lebanon and Politicization of Numbers}

In the acceptation and hosting of most foreigners (refugees and non-refugees) per capita, Lebanon is one of the World's leading countries. For this reason, the situation arising from a legal deficiency in guaranteeing the rights of refugees while managing and hosting the migration, which brings the country in an important international position, causes many more important problems in the country. The Lebanon government adopted an "open-door" policy against the Syrian crisis, which occurred in 2011, and allowed 1.5 million Syrians to cross the country. However, by 2014, the Lebanon government has decided to change the open-door policy that it had previously adopted and restricted the Syrians to access to basic services. In addition, from the end of 2014, the Lebanese 
government attempted to take limiting measures against Syrians although previously accepted with open door policy. In May 2015, Lebanese officials asked UNHCR to stop the records of Syrian migrants. Especially between the years 2016-2018, the policy towards Syrians was very radical and the immigrants in the country began to be seen as the main cause of instability, unemployment, and disruptions in institutions. This led to Foreign Minister Gebran Bassil's call for the return of Syrians and he said that the UN should not prevent the return of Syrians. Subsequently, it became mandatory to renew the residence permits in every 6 months, and persons became deprived of the rights of legal work. In addition, it is not legally arranged to benefit from education, travel and health services for Syrians and their children. Instead, the provision of these rights and the coordination of other necessary services were fully transferred to the ruling political party and local municipalities, which can significantly affect the size and process of the decisions (Geha, 2018, p. $1-2)$.

The religious distribution rate of the population, which develops a close relationship with the sharing of political power in Lebanon, still shows its effect. The main reason why Christian groups are brought forward and emphasised in this way is to ensure the political majority in Lebanon and to achieve political power (Maktabi, 1998, p. 240). However, even if the politicisation of the numbers ensures a power share within itself, the result often allows the production of those remaining outside. This offers a backdrop to the ongoing debate in Lebanon in the long run. While the socio-political structure of Lebanon increases the tendency of polarisation within itself, this situation has also led to the use of the Syrians as the subject of politicisation. The fact that the majority of the immigrants from Syria are Sunni Muslims is evaluated at different perspectives with the idea that the balance of political power ${ }^{7}$ created according to the population numbers in the country will be affected. In this aspect, in Lebanon, where the religious population has determined the sharing of political power, the Syrians are perceived as a danger to the existence of Christians, the threat of security to the existence of Shiites, and the economic threat to the Sunni Muslims. Lebanese politicians, therefore, support the return of Syrians to preserve the balance of population and politics in the country (Geha, 2018, p. 2-3), which leads to a reluctant policy for the citizenship and registration.

Lebanon is also a member of the following agreements, which will also support the agreement of the United Nations Convention on the Rights of the Child (CRC). The International Covenant on Civil and Political Rights (ICCPR), The Convention on the Elimination of all Forms of Discrimination Against Women (CEDAW), The International Convention on the Elimination of All Forms of Racial Discrimination (ICERD), Convention on the Rights of Persons with Disabilities (CRPD). However, Lebanon is not part of an agreement that commits refugee and citizenship rights in the international arena, such as The 1951 Refugee Convention (UNHCR), 1954 Convention Relating to the Status of Stateless Persons and 1961 Convention on the Reduction of Statelessness, which will make refugee and citizenship rights more important in particular for Turkey.

The first article of the Lebanese Citizenship Law theoretically commits to receiving citizenship in this way; Lebanese: (a) Every person born of a Lebanese father (b) Every person born in the Greater Lebanon territory and did not acquire foreign nationality, upon birth, by affiliation. (c) Every person born in the Greater Lebanon territory of unknown parents or parents of unknown

\footnotetext{
${ }^{7}$ According to the 1932 population election results, Lebanese President must be Marunî Christian, Prime Minister must be Sunni Muslim, and Parliament speaker must be Shiite Muslim.
}

Copyright @ 2020 BORDER CROSSING 


\section{Stateless Syrians in Turkey and Lebanon}

nationality ${ }^{8}$. According to this article, every child, born within the territory of Lebanon, or in cases where his or her parents' national belonging is questioned and not known, receives Lebanese citizenship. This situation theoretically provides a solution to the problem of statelessness in Lebanon, but if it is not implemented (ISI, 2016), it allows both a humanitarian crisis and a debate on law enforcement. In general, however, this article of the Lebanese citizenship law draws a similar framework with article 8 of the Turkish citizenship law. In other words, while being born within the borders of Lebanon and Turkey is open to the interpretation of the right of citizenship according to these articles, Muammer Güler, the interior minister of the period, said that these immigrants would not be able to get citizenship because their citizenship is known, bringing Turkey closer to Lebanon in terms of approaching the citizenship issue of Syrians.

The Syrians continue to live in Lebanon without legal rights, causing that they mostly settle in the Beqaa Valley, North and South Lebanon informally, while the lack of working rights exposes them to the exploitation of their labor and gendered attacks. The gap caused by the lack of legal basis also opposes the search for rights of the "de facto Syria citizens" in this direction (Geha, 2018, p. 2). Northern Lebanon and the Beqaa Valley are at the forefront compared to the other regions in terms of child registration rates (UNHCR, 2013, p. 55). The main reason for this is that migrants who immigrate there are both deprived of basic rights and economically disadvantaged. However, as discussed above in the case of Turkey, not being a citizen and not being included in the registration system bring double deprivation to the agenda. In this respect, statelessness leaves the individuals vulnerable to the outside dangers, while being unregistered prevents individuals from access to fundamental humanitarian rights.

The process of obtaining a birth certificate in Lebanon involves similar phases of procedures with the system in Syria. Having a Lebanese father as a prerequisite for the individuals to benefit from the basic human rights confines the state to a limited system of jus sanguinis, i.e. an inheritance-related system. In addition to this feature, having a registration certificate for their own children of Lebanese parents in Lebanon requires a rather complex, costly process and procedures to overcome. Because of these procedures, even citizens in Lebanon are sometimes unable to provide this opportunity to their children, thus, statelessness may be in question for even the Lebanese children. Due to this situation, which has reached a dangerous level for especially the Palestinian refugees, who constitute a significant population in the country before the Syrians, the Child Rights Committee (CRC) warned the State authorities about this and warned that newborns should be registered as soon as possible. This warning and suggestion, which did not cause sufficient progress even after some steps, did not reach the further stages for the Syrians in the short term. However, the process of obtaining the birth registration certificate by both foreigners and Lebanese citizens in the country prevents many families from receiving this document (ISI, 2016).

In Lebanon, it seems impossible for unregistered persons to benefit basic human rights. It is not possible for unregistered persons to take advantage of rights such as health, education, legal work and to pass through many checkpoints of the country for reasons of being caught or detained. However, in Lebanon, the prohibition of identification services given previously by neighborhood local administrators to the stateless/unidentified persons makes it difficult to prove their own existence, as well as, to demand fundamental rights. This does not only involve foreigners who come from outside but also severely affect the children of a Lebanese mother or immigrant parents

\footnotetext{
${ }^{8}$ https://www.refworld.org/pdfid/44a24c6c4.pdf (Date of Access: 01.02.2019)
} 
who are the citizen of another country. Because of the fact that it does not give equal rights to men and women, it constitutes a violation of CEDAW, ICCPR, and CRC in particular, and causes the country to differentiate from Turkey on an important issue. Considering the proportion of Palestinian refugees in the country, the de facto statelessness, which can reach serious numbers with marriage, extends even more important dimensions with the addition of Syrians (Wass, 2014, p.4). With this feature, it is possible to say that unlike Turkey, Lebanon also hosts a mechanism that reproduces the stateless generations in the de facto position. Consequently, a child of a Syrian father and a Lebanese mother cannot obtain Lebanese citizenship, and being deprived of basic human rights for children is preparing the ground for their confrontation with dual deprivation. In a study conducted on the proportion of Lebanese women marrying a foreign male (especially Palestinian), who had problems due to the deprivation of citizenship registration, only 18.000 marriages were reported to be made between 1995-2008 (Charafeddine, 2009, p. 17). It can be seen that some of the children born from these marriages have not been registered considering that there is no provision, some of them have been recorded (religious), but do not have any legal document of registration (Mutlu et al., 2016; ISI, 2016). However, an important problem that often overlooked by discussions on child registration is that a de jure statelessness generation without registration and/or citizenship will be an active member of the society in the future. It is necessary to say that the concept of citizenship is a self-responsibility and an identification in Foucault's definition (2000, p. 290). In other words, identification cannot bring a solution to the problem of statelessness of persons, but it is possible to allow them to use basic human rights and to be identified.

It is also important that Syrians have a family registry booklets. According to the registration procedures in Syria, the children can benefit from the State services by registered to the family registry until the age of 14 . However, according to a study in Lebanon, $80 \%$ of children whose age is 5 or below is not registered in the family registry booklet. The main reason is that the Syrians do not know how to get it, secondly, they think that they must receive the birth certificate from the Ministry of Foreign Affairs of Lebanon, and then the Syrian Consulate must be notified to record (NRC, 2017, p. 3). However, even if Syrians living away from their own State perform these processes, the non-functioning of civilian registrations in Syria due to unhealthy conditions (UNCHR, 2016, p. 10) will cause new problems. Indeed, in an interview with a father, when asked whether he completed the registration process of the newborn baby, he showed the birth certificate received from the hospital (UNCHR, 2013.56), indicating that Syrians are not sufficiently informed of the registration process. The research conducted by NRC (2017, p. 1-2) reveals statistical data in Lebanon. Research results indicate that only $23 \%$ of Syrians in Lebanon over the age of 14 have identity cards. In addition, $24 \%$ have no family registry booklet that shows family members and confirms the union of parents having the legal responsibility for the children and is changed by the addition of each newborn individual. As mentioned above, the fact that the registration process is different from the system of Syria causes the registration process of newborn babies not to be completed. As a result of studies in Lebanon, it was determined that infants who did not have birth notification were less than $5 \%$, while $92 \%$ were not able to complete all operations for the birth certificate. In this respect, it is concluded that families do not have information and think that the system runs only with the notification as in Syria (UNCHR, 2013, p. 56). Another study indicating that the registration procedures in Lebanon are insufficient is also based on the study of UNCHR (2013, p.55). According to the study, 77\% of 781 newborn babies do not have an official birth certificate. 


\section{Stateless Syrians in Turkey and Lebanon}

Lebanon has the advantage for Syrians because its alphabet is Arabic, and the language of Arab is used, so partially removing the problem of languages and communication. In this respect, the problem of Latinization in cases where the name of the child, father, and mother are recorded in the competent offices in Turkey and the problems that may cause later can be minimised. In addition, the social structure, daily life and relations in Lebanon are open to officially integrate the immigrant Syrians. As an extension of this, the Lebanese government decided to accept the Syrians' family registry booklets as a valid document for those without identification cards in 2013 (UNCHR, 2013, p. 56). However, as mentioned above, the main reason for insufficient registration is that the Syrians are not familiar with the system in Lebanon due to the different procedures in Syria. But, the problems experienced during the registration process in Turkey include many parameters such as language, culture, alphabet, and institutional functioning.

\section{Conclusion and discussion}

The registration of the newborn baby is the basic and starting point of the children's citizenship claim. This indicates that citizenship is the most important inherited heritage. After the second world war, hundreds of thousands of people, especially Jews, have remained stateless, or a problem has emerged at the global level because they were excluded from their country's citizenship. The establishment of new states and the fact that these states did not want to take this responsibility caused the international organisations to take action. Accordingly, the refugee agreement in 1951, subsequently the Convention Relating to the Status of Stateless Persons in 1954 for the resolution of the problem of statelessness resulting from the war, followed by the Convention on the Reduction of Statelessness in 1961 and the next agreements in the leadership of the United Nations tried to prevent the problem of statelessness considering it as a global issue. The problem of de facto statelessness left behind by the Syrian crisis, which is seen as the biggest historical event on a global scale after World War II, keeps its importance. When or whether the stability is to be provided in Syria is not known, but in the process of proving the status of being a Syrian citizen, it is likely that the mystery of what is waiting for the refugees will affect the return. In this way, despite the claim that hundreds of thousands of Syrian parents and infants and children are citizens of Syria, it is not possible to prove it in the current circumstances. However, it is necessary to prevent the children from being deprived of the basic human rights that begin with citizenship regardless of the parent's condition or some behaviors. Therefore, they must be ensured to benefit basic human rights by registering to the system of the country where the minimum level of person resides. Otherwise, the individuals may be subjected to a double deprivation with unregistered statelessness.

As a matter of national and international awareness, there are studies for the legal solution to the phenomenon of statelessness. In general, however, there is a tendency of the countries to protect the citizens of the countries becoming a party to a contract. The $1^{\text {st }}$ and $2^{\text {nd }}$ World Wars, the collapse of the Soviet Union in the 1990s and the problems in the Balkans and the civil war that started in the Middle East, especially in Syria and Iraq, caused millions of people to be born and lived outside their own territory. The fact that Syria is a neighbor to Turkey and Lebanon has enabled the migration of an important part of the immigrant population into the territory of these countries. As stated above, the sociological problems that have emerged with the inadequacy of practical arrangements for the phenomenon of statelessness which tried to be minimised by law cause the next generation to be deprived of national belonging. It is possible to express that both Turkey and Lebanon have gained an important position in the international arena due to the open door policies for the crisis in Syria. Comprehensive policies are being developed in coordinated activities with 
the UN. However, Turkey and Lebanon differentiate in the policies of status and social integration they have provided for Syrians. The unchanged political decision-makers in Turkey and decisions supporting the previous ones make it separate from Lebanon. In Lebanon, the establishment of a new government following May 6,2018, general elections were naturally followed by a change in the policies for previous Syrians. But beyond that, the change of political power based on the population has led to the politicisation of Syrians. Therefore, despite Lebanon's population of about 5 million and the economic situation that is proportional to it, it's open-door policy allowed an intensive migration population to enter the country in a very short period of time. However, this situation has led to the production of an opposite policy in the political arena in a short time due to the negative reflections on the social and economic base as seen above.

It can be stated that the situation of de facto statelessness discussed above in Turkey and Lebanon is mainly due to the following basic reasons. First of all, according to the Syrian constitution, citizenship is transferred only through the father, but one-quarter of the fathers died during the civil war, lost or were fighting, which caused the problem of citizenship for their children born in other countries. With a reverse reading, the mother's inability to transmit citizenship to the next generation prepares the ground for the growth of an unregistered and stateless generation. The second other reason is that the notification and registration of the newborn in Syria are being carried out at the same time, which is not known by individuals who are far from their own country. In Syria, the competent authorities were notified within 30 days if the baby was born in the territory of Syria and within 90 days if the baby was born abroad, so they were registered in the family registry booklet, and the families were not given any document. Especially due to this situation, it is seen that Syrian parents have reported the birth of their baby, however, this ratio has decreased considerably in the process of bringing all necessary documents for the registration process. The main reason for this is that the Syrians have to make a single step for notification and registration in their country, but these processess are made in different stages abroad. Besides considering it as a data, depending on the first reason, the mothers, who think that Syrian citizenship is granted only with the father, can not make a birth notification after the death of the father in the war, which can be seen as another reason for increasing nonregistration and statelessness. The third reason is that the registration process is deemed to be culturally insignificant and unnecessary. The delay of the registration process by Syrians both in Turkey and Lebanon by considering the possibility of the baby dying may cause the registration process to be interrupted. The fourth reason, which is based on security concerns, is that Syrians in both countries are unable to register with the fear of being stigmatised as a dissident by the government on possible returns. The fifth reason, which is one of the main reasons for nonregistration especially in terms of Turkey, is sourced from the thought of the Syrians to migrate to Europe using Turkey as a transit country. The individuals in this opinion do not realise the registration due to either considering it unnecessary or the idea of being deported to Turkey in the event of capture in the European way.

\section{References}

Adhikari, J. (2013). Refugees from Rakhine State of Myanmar and Urdu-Speaking Bihari Population in Bangladesh. Report of The International Consultation "Towards an Ecumenical Advocacy On Rights of Stateless People" (Ed. M. G. Chunakara). (Pp. 73-79). Washington: WCC Publications. 


\section{Stateless Syrians in Turkey and Lebanon}

AFAD (2013) Syrian Refugees in Turkey: Field Survey Results. Republic Of Turkey Prime Ministry Disaster And Emergency Management Presidency, Https://Www.Afad.Gov.Tr/Upload/Node/17949/Xfiles/Syrian-Refugees-InTurkey-2013_Print_12_11_2013_Eng_1_.Pdf

Altuğ, Y. (1963). Vatansızlar Hakkında İki Birleşmiş Milletler Sözleşmesi. İstanbul Üniversitesi Hukuk Fakültesi Mecmuas1, 29 (1-2), 201-217. Retrieved from Http://Dergipark.Gov.Tr/Iuhfm/Issue/9109/113946

Arslan, M. (2014). "Haymatlos” Kavramının Türkçedeki Serüveni. Türkbilig. (27). 121-135.

Ateş, A. (2017). Burma'dan Myanmar'a Arakan'da Rohingya Müslümanları. İstem. (29). 173-216.

Basavapatna, S. (2018). Where Do I belong? The Stateless Rohingya in India. The Rohingya in South Asia: People Without a State. (Ed. S., R. Chaudhury and R. Samaddar). New York: Routledge. Ss. (43-73). Https://Doi.Org/10.4324/9780429467677

Batchelor, C. A. (1998). Statelessness and The Problem of Resolving Nationality Status. International Journal of Refugee Law, 10 (1-2), Pp. 156-182, Https://Doi.Org/10.1093/Ijrl/10.1-2.156

Blitz, Brad K. (2009). Statelessness, Protection and Equality. Refugee Studies Centre.University of Oxford. Https://Www.Rsc.Ox.Ac.Uk/Files/Files-1/Pb3-Statelessness-Protection-Equality-2009.Pdf

Castles, S. and Miller, J. M. (1998). The Age of Migration: International Population Movements in The Modern World. (2. Bask1). London: Macmillan Press LTD.

Charafeddine, F. (2009). Predicament of Lebanese Women Married Ton On-Lebanese. Rasbeirut, Kraitem, Beirut: Karaky Printing Press.

Foucault, M. (2000). Hapishanenin Doğuşu. (Çev. M. A. Kılıçbay). Ankara: Imge Yayınevi

Gale, E. D. (2016). Statelessness Risk of Syrian Refugee Children Born in Turkey. Unpublished Master Thesis. Tilburg University

Geha, Carmen (2018). Politics and The Plight of Syrian Refugees in Lebanon. Https://Www.Aub.Edu.Lb/Documents/Politics-And-The-Plight-Of-Syrian-Refugees-In-Lebanon.Pdf

ILAC (2017), Rule of Law Assessment Report, (Ed. M. Ekman). Http://Www.Ilacnet.Org/Wp-Content/Uploads/2017/ 04/Syria2017.Pdf

ISI (2016). Lebanon Civil Society Submission On The Right Of Every Child To Acquire A Nationality Under Article 7 CRC Http://Www.Institutesi.Org/CRC_Lebanon_2016.Pdf

KDK (2017), Türkiye'de Suriyeliler. Özel Rapor. Https://Www.Ombudsman.Gov.Tr/Suriyeliler/Ozel_Rapor.Pdf

Mackreath, H. And Gülfer Sağnıç, Ş. (2017). Civil Society and Syrian Refuges in Turkey. İstanbul. Citizens' AssemblyTurkey.

Maktaba, R. (1999). The Lebanese Census of 1932 Revisited. Who Are the Lebanese? British Journal of Middle Eastern Studies 26(2). 219-241.

Malischewski, C.-A. (2018). Legal Brief On Statelessness: Law in The Indian Context. The Rohingya in South Asia: People Without a State. (Ed. S., R. Chaudhury and R. Samaddar). New York: Routledge. Ss. (134-159). Https://Doi.Org/10.4324/9780429467677

Massey, H. (2010). UNHCR and De Facto Statelessness. Legal and Protection Policy Research Serıes. UNHCR Geneva. Mutlu, Y., Kırımsoy, E., Antayalığlu, Ş. (2016). Bulanık Mekanlarda Gölgede Kalanlar: Suriyeli Mülteci Çocuklar Ve Vatansızlık Riski Araştırma Raporu. Http://Www.Madde14.Org/Images/F/F0/Gundemcocuk bulanik mekanlarda 2016tur.Pdf

NRC (NORWEGIAN REFUGEE COUNCIL). (2017). Syrian Refugees' Right To Legal Identity: Implications For Return (Briefing Note) Https://Www.Nrc.No/Globalassets/Pdf/Briefing-Notes/Icla/Final-Syrian-Refugees-CivilDocumentation-Briefing-Note-21-12-2016.Pdf

OCHA (2017). Humanitarian Bulletin Lebanon. Https://Reliefweb.Int/Sites/Reliefweb.Int/Files/Resources/OCHAHumanitarianbulletin-Issue28-31july2017.Pdf

Özbek, N. H. and Teksoy, B. (2013). Vatansızlığın Azaltılmasına Dair BM Sözleşmesi (1961) Karşısında Türk Vatandaşlığı Kanunu. TBB Dergisi (107). 221-244

Reynolds, S. and Grisgraber, D. (2015). Birth Registration in Turkey: Protecting The Future for Syrian Children. Refugees International: Washington.

Sengupta, S. (2018). Stateless, Floating People: The Rohingya at Sea. The Rohingya in South Asia: People Without a State. (Ed. S., R. Chaudhury and R. Samaddar). (pp. 20-42). New York: Routledge. Https://Doi.Org/ $10.4324 / 9780429467677$

UN, (1954). Convention Relating to The Status of Stateless Persons. Geneva: UNHCR

UN, (1989). Convention On the Rights of the Child. Https://Www.Ohchr.Org/Documents/Professionalinterest/Crc.Pdf

UNHCR (2018). Civil Documentation and Registration in The Syrian Arab Republic. Https://Www.Unhcr.Org/Sy/WpContent/Uploads/Sites/3/2018/09/Personal-Documentation-En-Jul-2018.Pdf 
UNHCR, (2013). Resolving Existing Major Situations of Statelessness: Ending Statelessness Within 10 Years. Https://Www.Refworld.Org/Pdfid/54e75a244.Pdf

UNHCR, (2013). The Future of Syria: Refugee Children in Crisis. Https://Www.Refworld.Org/Pdfid/529c3b4d4.Pdf

UNHCR, (2014) Woman Alone: The Fight For Survival By Syria's Refugee Women, Https:/Www.Refworld.Org/ Docid/53be84aa4.Html

UNHCR, (2015), I Am Here, I Belong the Urgent Need to End Childhood Statelessness. Https://Www.Unher.Org/ Ibelong/ Wp-Content/Uploads/2015-10-Statelessreport_ENG16.Pdf

UNHCR, (2016) Addressing Statelessness in The Middle East and North Africa. Https:/Www.Refworld.Org/ Docid/57dbdaba4.Html

UNHCR, (2016). Evaluation of UNHCR's Emergency Response to The Influx of Syrian Refugees into Turkey. Https:/Www.Unhcr.Org/Research/Evalreports/58a6bbca7/Evaluation-Unhcrs-Emergency-Response-Influx-SyrianRefugees-Turkey-Full.Html

UNHCR, (2019) Https://Data2.Unhcr.Org/En/Situations/Syria

Velath, P. M. And Chopra, K. (2018). The Stateless People: Rohingya in Hyderabad. The Rohingya in South Asia: People Without a State (Ed. S., R. Chaudhury and R. Samaddar). (pp. 74-90). New York: Routledge. Https://Doi.Org/ $10.4324 / 9780429467677$

Wass, L. V. (2014). Citizenship, Statelessness and The Numbers Game in Lebanon, Statelessness Program. Tilburg University.

Http://Www.Goc.Gov.Tr/Files/Files/Eng_Minikanun_5_Son.Pdf

Https://Www.Refworld.Org/Pdfid/44a24c6c4.Pdf

Https:/Www.Tbmm.Gov.Tr/Tutanaklar/KANUNLAR_KARARLAR/Kanuntbmmc058/Kanuntbmmc058/Kanuntbmmc 05801883.Pdf

Https:/Www.Unhcr.Org/42bc068d2.Pdf 